Keywords: Cement, grout, Saltstone, concrete, biodegradation,

Retention: Permanent

\title{
Review of Concrete Biodeterioration in Relation to Buried Nuclear Waste
}

\author{
Charles E. Turick and Christopher J. Berry \\ Environmental Science and Biotechnology \\ Savannah River National Laboratory
}

August 2012

Savannah River National Laboratory Savannah River Nuclear Solutions, LLC Aiken, SC 29808

Prepared for the U.S. Department of Energy under

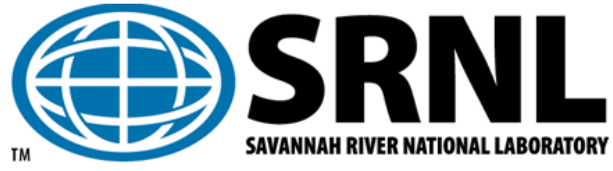
contract number DE-AC09-08SR22470. 
SRNL-STI-2012-00435

Revision 0

\section{DISCLAIMER}

This work was prepared under an agreement with and funded by the U.S. Government. Neither the U.S. Government or its employees, nor any of its contractors, subcontractors or their employees, makes any express or implied:

1. warranty or assumes any legal liability for the accuracy, completeness, or for the use or results of such use of any information, product, or process disclosed; or

2. representation that such use or results of such use would not infringe privately owned rights; or

3. endorsement or recommendation of any specifically identified commercial product, process, or service.

Any views and opinions of authors expressed in this work do not necessarily state or reflect those of the United States Government, or its contractors, or subcontractors.

\section{Printed in the United States of America \\ Prepared for U.S. Department of Energy}


SRNL-STI-2012-00435

Revision 0

\section{EXECUTIVE SUMMARY}

Long-term storage of low level radioactive material in below ground concrete disposal units (DUs) (Saltstone Disposal Facility) is a means of depositing wastes generated from nuclear operations of the U.S. Department of Energy. Based on the currently modeled degradation mechanisms, possible microbial induced effects on the structural integrity of buried low level wastes must be addressed. Previous international efforts related to microbial impacts on concrete structures that house low level radioactive waste showed that microbial activity can play a significant role in the process of concrete degradation and ultimately structural deterioration.

This literature review examines the recent research in this field and is focused on specific parameters that are applicable to modeling and prediction of the fate of concrete vaults housing stored wastes and the wastes themselves. Rates of concrete biodegradation vary with the environmental conditions, illustrating a need to understand the bioavailability of key compounds involved in microbial activity. Specific parameters require $\mathrm{pH}$ and osmotic pressure to be within a certain range to allow for microbial growth as well as the availability and abundance of energy sources like components involved in sulfur, iron and nitrogen oxidation. Carbon flow and availability are also factors to consider in predicting concrete biodegradation.

The results of this review suggest that microbial activity in Saltstone, (grouted low level radioactive waste) is unlikely due to very high $\mathrm{pH}$ and osmotic pressure. Biodegradation of the concrete vaults housing the radioactive waste however, is a possibility. The rate and degree of concrete biodegradation is dependent on numerous physical, chemical and biological parameters. Results from this review point to parameters to focus on for modeling activities and also, possible options for mitigation that would minimize concrete biodegradation. In addition, key chemical components that drive microbial activity on concrete surfaces are discussed. 


\section{TABLE OF CONTENTS}

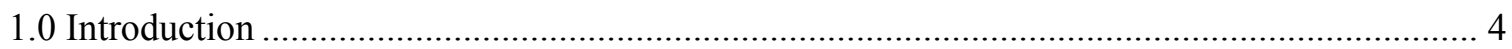

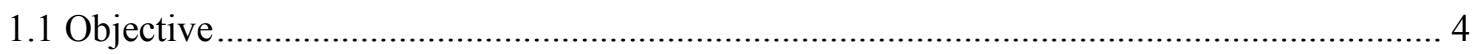

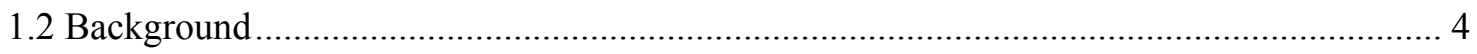

2.0 Chemical composition of saltstone waste form and the saltstone Disposal Facility concrete

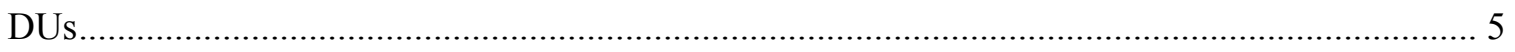

3.0 Physiochemical factors that influence microbial activity ................................................... 6

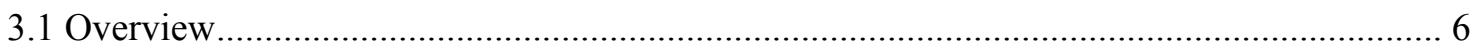

3.2 Impact of physicochemical parameters on saltstone and SDF concrete DUs ....................... 9

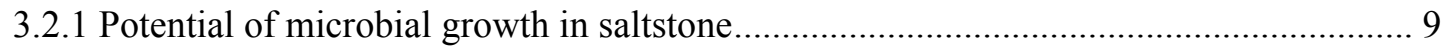

3.2.2 Potential of microbial growth on SDF concrete DUs................................................. 9

4.0 Biochemical and geochemical factors that influence microbial activity ............................... 9

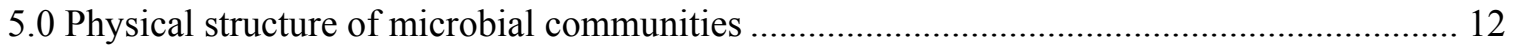

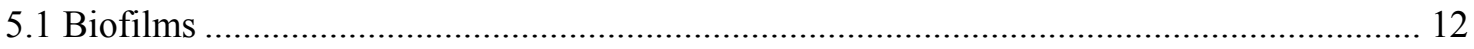

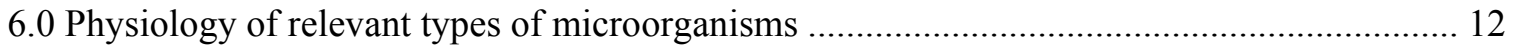

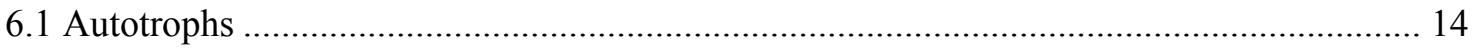

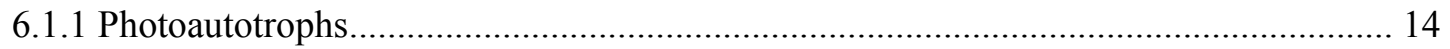

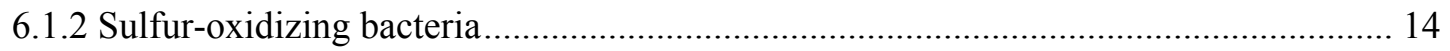

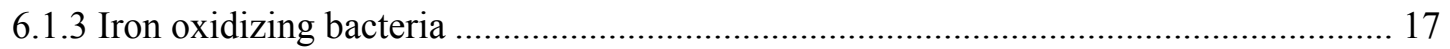

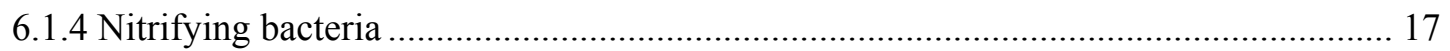

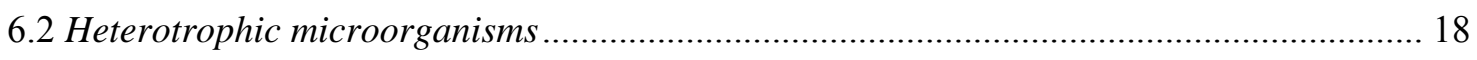

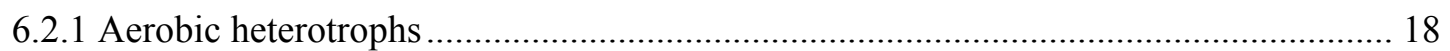

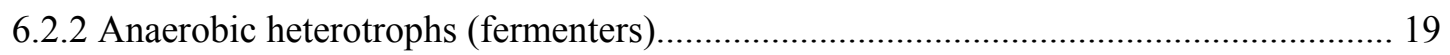

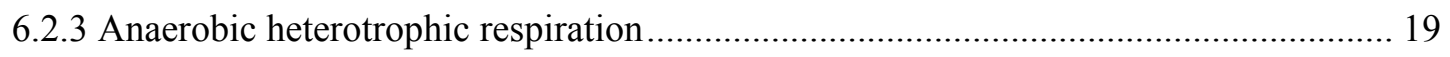

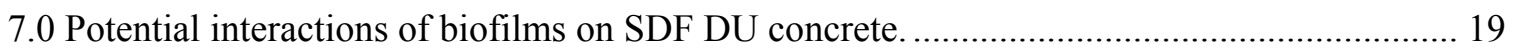

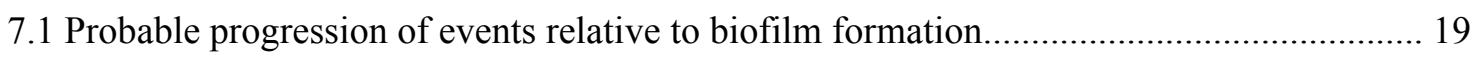

8.0 Considerations for predicting and minimizing biofilm formation of concrete and

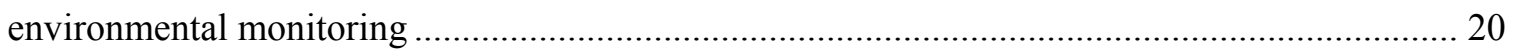

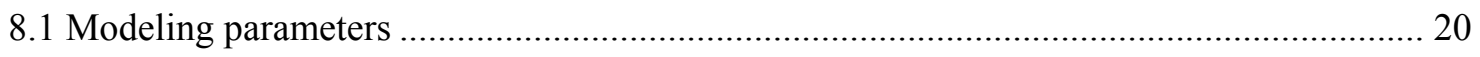

8.2 Considerations for minimizing biofilm formation on buried concrete DUs ...................... 20

8.3 Insights for future environmental monitoring approaches ............................................. 21

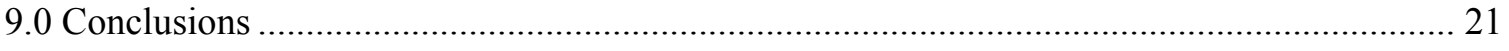

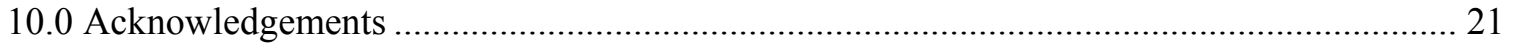

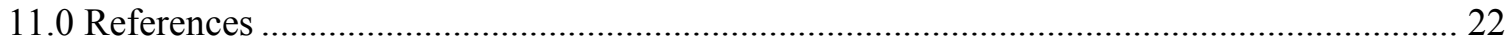




\section{LIST OF TABLES}

Table 1. Types of microorganisms and physiologies involved in reactions on concrete ........13

Table 2. Strengths of some microbial acids which react with concrete and the solubility's of the associated calcium salts of concrete matrices............................................ 13

Table 3. Strengths of some acids which react with concrete and the solubility's of the associated

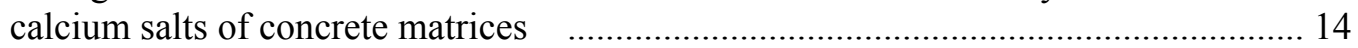

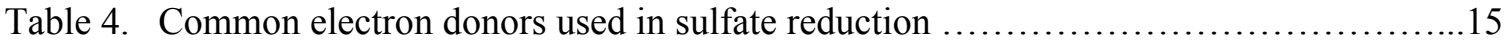

\section{LIST OF FIGURES}

Figure 1. Temperature and microbial growth rates......................................

Figure 2. Common terminal electron acceptors.......................................... 8

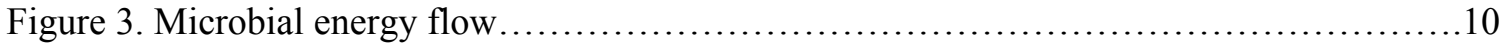

Figure 4. Depiction of the role of microorganisms in nitrogen cycling ........................ 18

\section{LIST OF ABBREVIATIONS}

$\begin{array}{ll}\mathrm{a}_{\mathrm{w}} & \text { Available water } \\ \text { DLVO } & \text { Derjaguin-Landau-Verwey-Overbeek } \\ \text { DU } & \text { Disposal units } \\ \text { DO } & \text { Dissolved oxygen } \\ \text { DOE } & \text { Department of Energy } \\ \text { IOB } & \text { Iron oxidizing bacteria } \\ \text { LLW } & \text { Low level radioactive waste } \\ \text { SDF } & \text { Saltstone disposal facility } \\ \text { SOB } & \text { Sulfur oxidizing bacteria } \\ \text { SRB } & \text { Sulfur reducing bacteria } \\ \text { SRNL } & \text { Savannah River National Laboratory } \\ \text { TEA } & \text { Terminal electron acceptor } \\ \text { XDLVO } & \text { Extended Derjaguin-Landau-Verwey-Overbeek }\end{array}$


SRNL-STI-2012-00435

Revision 0

\subsection{Introduction}

\subsection{Objective}

Low level radioactive wastes (LLW) generated from nuclear operations of the U.S. Department of Energy (DOE) are disposed for long-term storage in below ground containment. LLW containment is composed of two component parts; 1) concrete DUs that contain LLW inside their walls, and 2) LLW that is stabilized by solidification through grouting prior to disposition inside the concrete DUs. The concrete DUs consist of two types: rectangular vaults and cylindrical cells. Initially the rectangular vaults (DUs 1 and 4) are above ground and will be buried underground at site closure after they are filled with LLW. The 64 cylindrical cells are backfilled after construction with only the roof of the cells above ground and will also be buried at site closure.

The grouted waste form is referred to as saltstone. The rationale behind disposing saltstone waste inside concrete DUs is to isolate wastes contaminated with long-lived and/or highly mobile radionuclides from environmental exposure and to minimize the environmental impact of the materials and associated leachates over time. The saltstone wastes, when stored in concrete DUs are expected to remain immobile in the environment for an extended time[1]. Nonradioactive but toxic metals and other inorganics also pose a potential concern to soils and groundwater if they escape from storage.

It is important to understand the long-term structural integrity and resiliency of the concrete DUs and grout formations contained inside in order to predict the ability of the concrete to contain contaminants over hundreds of years. One significant contributing factor to the long-term stability of these structures is microbial activity. Based on the currently modeled degradation mechanisms, possible microbial induced effects on the structural integrity of buried low level wastes must be addressed[2]. Previous efforts elsewhere demonstrated that microbially influenced degradation of cementitious materials is common and may jeopardize the structural integrity of concrete structures[3]. In general, a microbial influence to concrete degradation results in the production of mineral or organic acids by the microbes that dissolve or disintegrate the concrete matrix.

\subsection{Background}

Previous work related to microbial impacts on concrete structures in which LLW in saltstone was stored showed that microbial activity can play a significant role in the process of concrete degradation and ultimately structural deterioration $[1,3,4]$. Since then, biodegradation of concrete structures was demonstrated to be a common occurrence; however, various microbial populations and mechanisms were shown to play different roles at different locations[5-7]. As a result, microbial assays designed to determine the rate of concrete biodegradation proved useful in evaluating concrete properties but were not a good predictor of environmental impacts on concrete[ $[8,9]$. Specific environmental conditions to which concrete is exposed, at any given location must be considered in order to understand environmental impacts on concrete biodeterioration[10].

Successful approaches to modeling concrete biodegradation will likely be most successful if they take concrete composition and specific environmental parameters (including microbiological composition) into account at each location. A number of modeling approaches have been undertaken that incorporate environmental conditions and simulate the degradation of organic matter as well as associated biogeochemical changes. A process based modeling approach will 
be useful in predicting microbial mediated reactive processes [11], like concrete biodegradation. Such an approach requires detailed characterization of the environment, materials and microbial activity [12] that would be deleterious to concrete structures.

This literature review will focus on the biodegradation of concrete, paying particular attention to the various physiological aspects of microorganisms that control concrete biodegradation and also the physical and chemical parameters that control microbial activity. It will focus more on the types of microbial physiologies and effects, with less attention to species names, since it is important to pay more attention to environmental niches than any particular species for several reasons. Due to species richness in the environment and our dearth of information regarding microbial species in the environment, it is likely that significant species variability will exist from place to place even though the same biogeochemical processes are occurring [5, 13]. Our findings are meant as a guide for use by environmental modelers for determination of, and prediction of, the stability of concrete structures in various environments. This review may also serve as a guide in the construction of future structures for LLW storage in order to reduce concrete biodegradation.

In addition, considering the increased interest in long-term subsurface monitoring as a means of quality control for buried LLW $[14,15]$, the results presented here may also be useful in guiding future activities in this regard toward technically reliable and cost effective applications. Specific biogeochemical traits in the subsurface may prove useful to monitor regarding the subsurface condition of the buried concrete and its structural stability.

Physicochemical factors control, to a large extent, the distribution and metabolic activity of subsurface microorganisms, and in turn, microbial activity results in changes in physicochemical parameters. Understanding how these factors contribute to biogeochemical changes and the dynamics of these processes is necessary in order to predict potential degrading microbial activity. Conditions such as: $\mathrm{pH}$; Eh; carbon source and concentration; moisture level; terminal electron acceptor type, concentration and bioavailability, are not homogeneous in the subsurface but their gradation provides evidence of microbial transformations and a foundation to monitor the progress of microbial activity and potentially concrete biodegradation [12].

\subsection{Chemical composition of saltstone waste form and the saltstone Disposal Facility concrete DUs}

The existing Saltstone Disposal Facility (SDF) DUs (i.e. DUs 1 and 4) are above grade, roofed, reinforced concrete DUs into which saltstone is poured. Saltstone is a grout consisting of lowlevel radioactive salt solution mixed with blast furnace slag, fly ash, and cement, which solidifies to form a dense, microporous, monolithic, low-level radioactive waste. The blend of grout reagents in SDF has been nominally (45 weight percent [wt\%] Grade 100 slag cement, $45 \mathrm{wt} \%$ Class F fly ash, and 10-wt\% Type I/II Portland cement) [16]. Physical characteristics of the DU space for the SFD were described by Dixon [17]. DU 1 is an above grade, rectangular shaped, reinforced concrete vault. It is approximately 600 feet $(183 \mathrm{~m})$ long, 100 feet $(30.5 \mathrm{~m})$ wide, and 25 feet $(7.6 \mathrm{~m})$ high. It is divided into 6 approximately 100 -foot $(30.5 \mathrm{~m})$ by 100 -foot $(30.5 \mathrm{~m})$ cells [18].. DU 4 is approximately 200 feet wide, 600 feet in length and 25 feet in height. DU 4 is divided into 12 cells with each cell measuring about 100 feet by 100 feet (by 25 feet in height) $[17,19]$. The walls, roofs, and floors of DUs 1 and 4 consist of reinforced concrete consisting of type II Portland cement, water, sand, aggregate, and slag Typically, the concrete mix consisted of 
11 wt $\%$ Type II Portland cement (ASTM C 150), 7 wt $\%$ water, 29 wt $\%$ sand (ASTM C 33), 46 wt $\%$ aggregate (ASTM C 33), and 7 wt $\%$ slag (ASTM C 989).

The cylindrical DUs consist of reinforced concrete having an internal diameter of 150 feet with a wall height of 22 feet. Typically, the concrete mix consists of $6 \mathrm{wt} \%$ Type V Portland cement (ASTM C150), $7 \mathrm{wt} \%$ slag (ASTM C989), $1 \mathrm{wt} \%$ silica fume (ASTM C1240), $4 \mathrm{wt} \%$ fly ash (ASTM C618), $26 \mathrm{wt} \%$ sand (ASTM C33), $48 \mathrm{wt} \%$ aggregate (ASTM C33) and $7 \mathrm{wt} \%$ water.

Details of the concrete mixes and their use in specific locations in the SDF are available in Dixon 2008 and Flach 2009 [18, 20]. Details of cement constituents, cement chemistry and concrete structure are discussed by Rogers 1993 [1].

Computer modeling, saltstone simulants, and cored saltstone samples have been analyzed to determine physical properties of the saltstone and what constituents will likely be released from the waste form. Early modeling results indicated that nitrogen release in the form of nitrate and nitrite was of concern [21-23]. Nitrate release rates were modeled using a one dimensional model by Hiergesell and Cook in 2005 for different saltstone DU wall thicknesses[24]. The hydraulic conductivities, porosities, and other physical parameters have been measured using core samples and simulant samples by Dixon, Nichols, Phifer, Williams, and others [17, 25-29]. These parameters are important for transport modeling of water in the SDF. Distribution coefficient determination and measurement studies have also been done by Almond, Hoeffner, Kaplan, and Roberts [22, 30-32]. Quantification of distribution coefficients allows more accurate modeling of the SDF and provides data for the vault design and design of DUs and closure caps [33]. Characterization and toxicity characterization leachate testing has been done on actual saltstone materials [34-36]. The results have shown some inorganics but not organics leaching from the saltstone material. In general, it was found that the chemical properties of the core sampled material are representative of the expected waste form [35].

\subsection{Physiochemical factors that influence microbial activity}

\subsection{Overview}

\subsubsection{General principals}

Considering the vast diversity of microorganisms and their capacity to grow in harsh environments, the following parameters provide some guidance as to potential rates of microbial activity under different conditions as stated in the literature. It should be understood though, that the main tenant of microbial ecology is; "everything is everywhere, the environment selects". As a result it is not unusual to see the same rates of microbial activity at very different conditions. These environments have most likely selected different species with different growth optima specific to their own environment, but all of the organisms may demonstrate comparable optimum growth rates.

\subsubsection{Temperature}

Microbial communities in the environment demonstrate a continuum of organisms with various growth rates dependent on temperature (Fig. 1). Microbial activity is driven by intracellular biochemical catalysts (enzymes) and can be regarded as following Arrhenius-type laws. 
Generally speaking, these laws describe a doubling of growth rate for every $10^{\circ} \mathrm{C}$ increase in temperature. That is, until thermal inactivation is reached as a result of enzyme denaturation [37]. This of course is unique for each microorganism because they have evolved different enzymes for optima at different conditions. And, when thermal inactivation occurs in one species, there is usually another that has adapted to the higher temperature. In general, temperatures between $10^{\circ} \mathrm{C}$ and $45^{\circ} \mathrm{C}$ will occur throughout the year in surface environments and the vadose zone, where LLW is being stored and reflect aboveground temperatures. Higher temperatures are likely at the soil surface during summer. By regarding the microbial community as a whole, increased rates of activity will likely occur as a function of temperature in the temperature range of $10-45^{\circ} \mathrm{C}$.

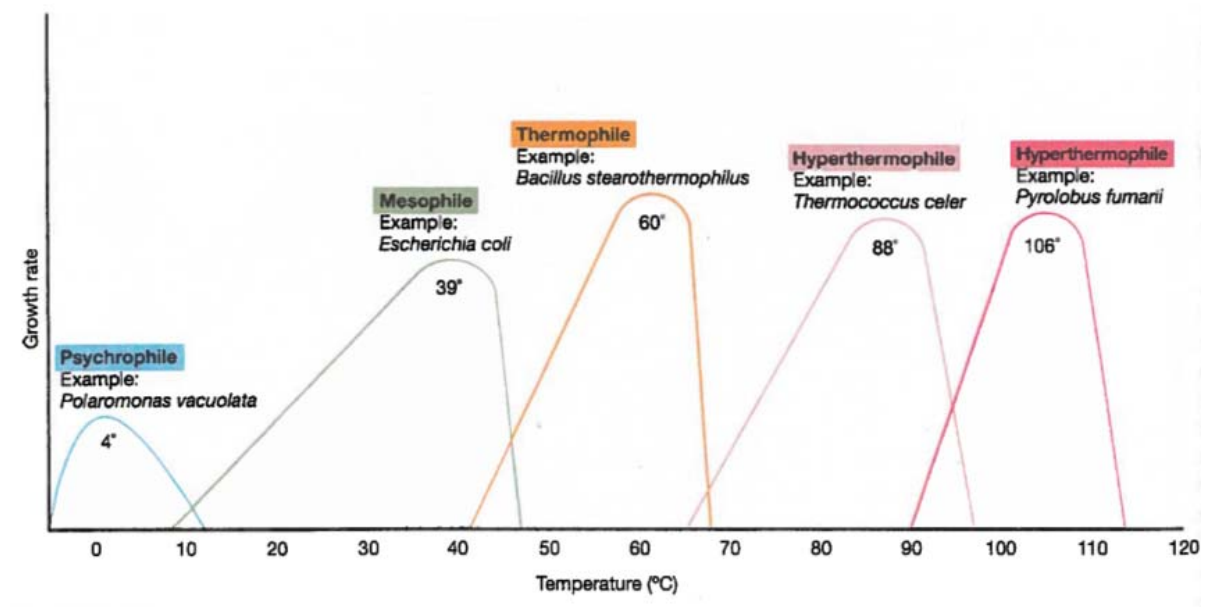

Figure 1. Temperature and microbial growth rates . Relation of temperature to growth rates of bacteria typical to their temperature class with temperature optima of the example organisms shown on the graph. (From: Madigan, M.T., J. Martinko, and J. Parker . 2003 [38])

\subsubsection{Water availability}

Microorganisms can be viewed as aquatic organisms with the understanding that in terrestrial systems, restrictions to water availability apply. Water availability can be expressed as water activity $\left(\mathrm{a}_{\mathrm{w}}\right)$, a ratio of air vapor pressure in equilibrium with a solution to that of pure water. Water activity, $a_{w}$, values are from 0 to 1 , with most agricultural soils between 0.9 and 1 . In general, microbial activity occurs at $\mathrm{a}_{\mathrm{w}}$ values from $1-0.6$, with fungi usually more tolerant of low moisture conditions. During excessively dry conditions, many microorganisms are not metabolically active but instead are dormant, through a number of mechanisms, including sporulation.

\subsubsection{Osmotic pressure}

Salt concentrations can alter the $\mathrm{a}_{\mathrm{w}}$ and thereby affect microbial growth. Microorganisms range in tolerance to salt concentrations from very low $(<1 \%)$ to as much as $15 \%$ [39]. While most halotolerant microbes grow better without higher osmotic pressure, extreme halophiles can thrive at sodium chloride concentrations from $15-30 \%$ [39]. 


\subsection{5 $\mathrm{pH}$}

Typically microbial activity is optimal around neutral $\mathrm{pH}$. But overall, growth ranges from $\mathrm{pH}$ values from around 1 to 10 , with some exceptions outside this range. Generally speaking, fungi are usually more active in lower $\mathrm{pH}$ soils than bacteria. Internal $\mathrm{pH}$ of microbes is around 7. External $\mathrm{pH}$ values are often a result of microbial activity. Microbial biofilms can also have a $\mathrm{pH}$ buffering effect upon contact with external liquids.

\subsubsection{Eh}

The redox potential of soils relates to the balance between oxidizing and reducing conditions in the soil matrix and can be controlled by chemicals present in the soils. For instance, oxygenated soils demonstrate more positive redox conditions compared to anaerobic soils. Regarding microbial activity, aerobic microbial growth and respiration is generally favored in soils with oxidizing redox conditions while anoxic soils favor anaerobic growth and fermentation. The range of redox conditions in soils can favor specific metabolic functions of microorganisms and hence, specific physiological types of microbes. Figure 2 illustrates the range of redox conditions in soils and associated biogeochemical activities.

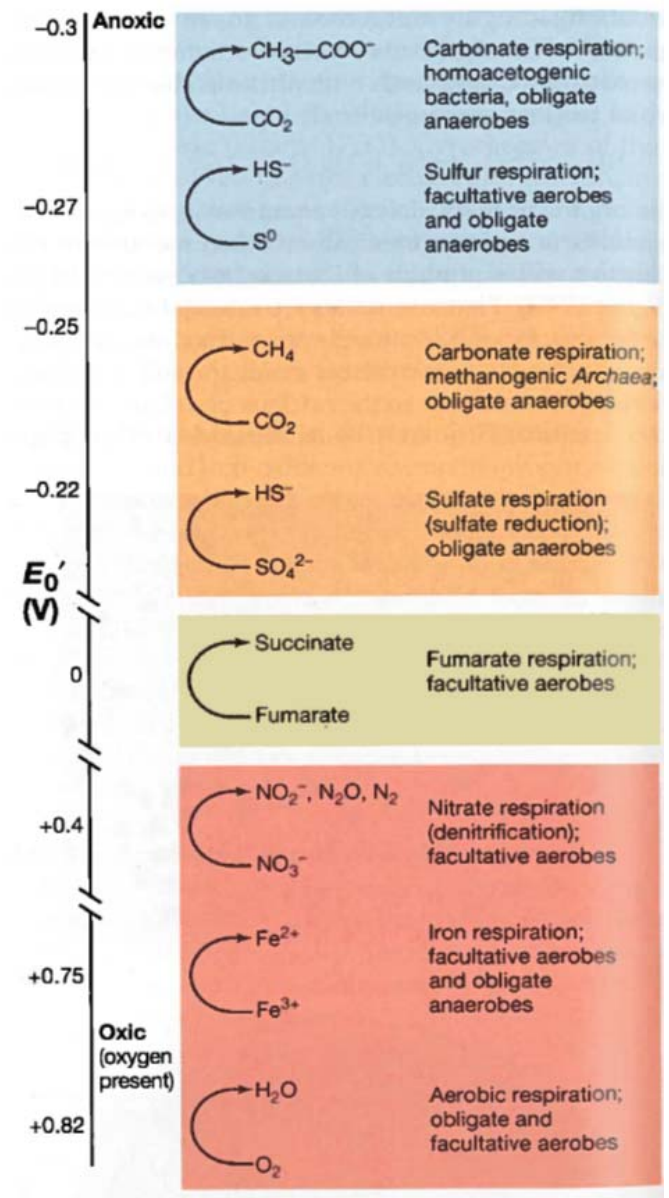

Figure 2. Common terminal electron acceptors. Examples of common terminal electron acceptors for microbial respiration and associated half-cell potentials $\left(\mathrm{E}_{0}{ }^{\prime}\right)$ of redox couples. (From: Madigan, et al. 2003. Biology of Microorganisms. p. 576 [38]). 


\subsection{Impact of physicochemical parameters on saltstone and SDF concrete DUs}

\subsubsection{Potential of microbial growth in saltstone}

The extremely harsh condition of the saltstone grout containing LLW suggests that microbial activity will not occur in the contained grout. The very alkaline conditions and extreme salt concentrations present are outside of recognized microbial growth conditions, especially relative to $\mathrm{pH}$ and osmotic stress. Consequently, while contaminants in saltstone grout are contained in concrete DUs, microbial activity is extremely unlikely to influence the saltstone chemistry.

\subsubsection{Potential of microbial growth on SDF concrete DUs}

Considering the resilient and robust nature of microbial activity, most "harsh" growth conditions encountered outside of the concrete DUs housing the grout will only minimize growth but not prevent it. For example, maintaining very dry conditions will likely lead to $a_{w}$ values low enough to drastically reduce microbial activity, but it seems unlikely that soils in the vadose zone can be maintained at $a_{w}$ values below 0.7 . As a result growth outside of the saltstone facility, which is on the outside surface of the concrete, appears most likely and practically unavoidable.

Based on this assessment, the greatest potential of microbial activity is on the surface of the concrete DUs and the likelihood of concrete biodegradation from concrete exposed to the natural environment and associated microorganisms is high. While the information above provides some guidance as to limits of microbial activity, the robust and adaptive nature of microorganisms must also be considered.

As an example, studies involving 3 climate areas that included climate regions with stable temperatures between $20-23^{\circ} \mathrm{C}$ but demonstrating extremes in humidity and a third with high humidity but low average temperatures (often at or below freezing), did not demonstrate significant differences in the degrees of concrete biodegradation [13]. This may be due to some degree of environmental buffering provided by the subsurface and/or the metabolic and physiological resilience of microorganisms under various conditions, whereby different conditions may select for different species of microorganisms with similar optimal metabolic rates. This example illustrates how microbial communities can demonstrate overlapping growth rates even though they encounter different environmental conditions. Figure 1 provides a good example of overlapping growth rates spanning over $110^{\circ} \mathrm{C}$.

\subsection{Biochemical and geochemical factors that influence microbial activity}

\section{$\underline{4.1 \text { Microbial growth on concrete }}$}

\subsubsection{Rationale}

From this point on this review will focus on key geochemical and biochemical parameters that appear to play significant roles on the outer surface of concrete DUs as it relates to concrete biodegradation at the interface between concrete structures exposed to air or in the vadose zone. In addition, we will also focus of specific microbial physiologies that are pertinent in the acceleration of these biogeochemical interactions. The referenced literature provided here is expected to be useful in model development in order to predict the rates and degrees of microbial activity of specific biogeochemical niches as well as the microbial ecology as a whole. These 
data will be useful with existing predictive models [12] and in the development of new models that predict the rates and degrees of concrete biodegradation under various external factors.

\subsubsection{Overall considerations of energy flow related to microbial activity and growth}

When conditions fall within all of the physiochemical parameters outlined above, microbial activity and growth will likely proceed, provided there is an energy source for microbial metabolic activity and a carbon source for growth. Energy sources include organic carbon, hydrogen or some reduced inorganic compounds like hydrogen sulfide $\left(\mathrm{H}_{2} \mathrm{~S}\right)$ or iron sulfide $(\mathrm{FeS})$. In the case of photosynthetic organisms like eukaryotic algae and cyanobacteria, light is a source of energy that drives metabolic activity.

Metabolic activities involve coupling the oxidation of an energy source to the reduction of a terminal electron acceptor (TEA), resulting in the conservation of energy used for cellular activities. The most energetically efficient means of metabolic energy generation is respiration. Based on its relative ubiquity and energetic potential, oxygen is a superior TEA and hence aerobic respiration yields the most energy in this process. In the absence of oxygen, some microorganisms can undergo anaerobic respiration by using other oxidized inorganic compounds like nitrates, sulfates, etc. as depicted in Figure 2, or in some cases oxidized organics [40, 41]. Under anaerobic conditions, metabolic energy generation may also be derived from fermentation. This is a less energetically efficient process than respiration and can result in incomplete conversion of organic compounds. Figure 3 provides a good generalization of carbon and energy flow in microbial systems in the subsurface. The availability and concentrations of these chemicals along with conducive physical and chemical conditions (temperature, $\mathrm{pH}$, Eh, etc.) will determine the dominant type(s) of microbial activity at any given location.

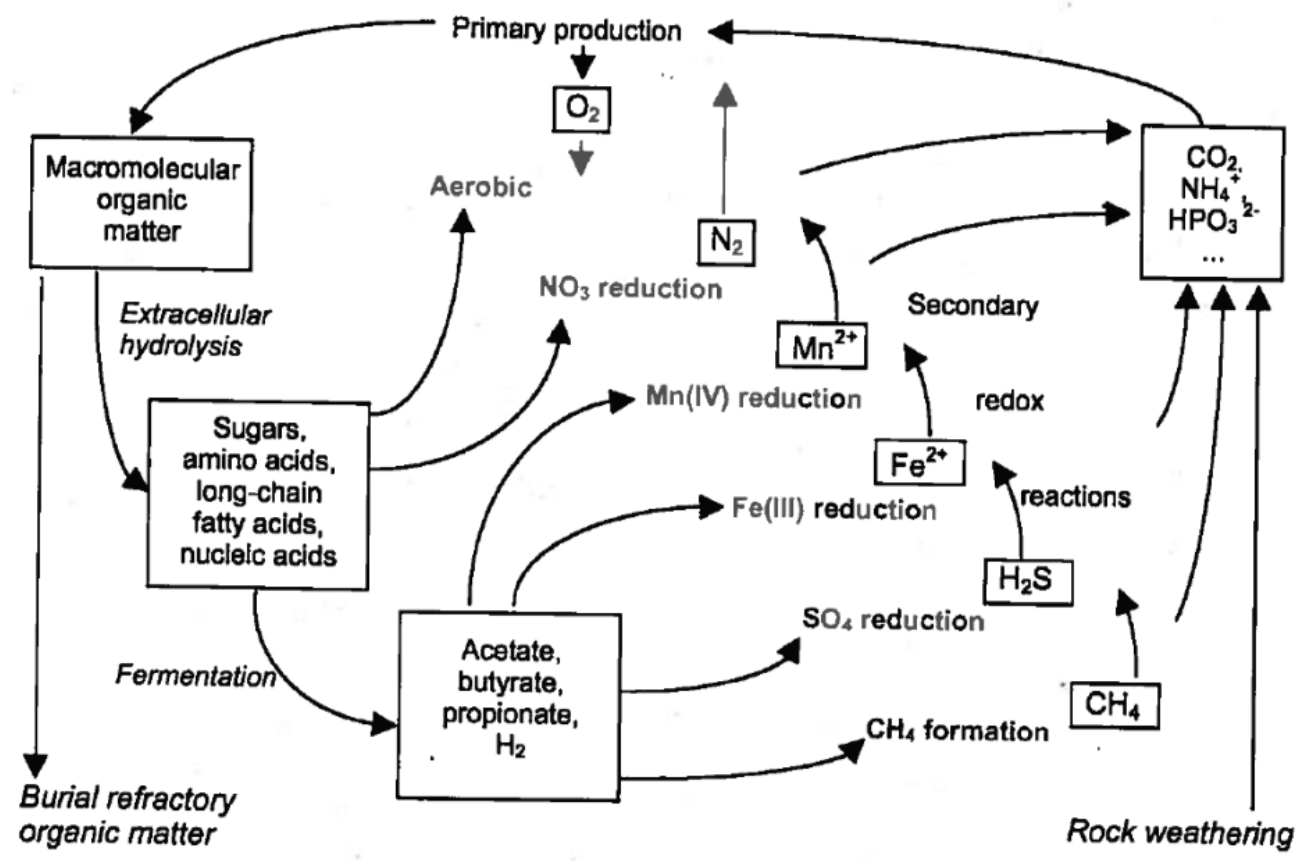

Figure 3. Microbial energy flow. General overview of reaction pathways and redox species involved in microbial ecology of the subsurface. (From: Thullner et al. [11]). The availability and concentrations of these chemicals play a significant role in determining the dominant type(s) of microbial activity at any given location. 
SRNL-STI-2012-00435

Revision 0

\subsection{Carbon}

\subsubsection{Inorganic carbon}

Microbial growth is a function of available carbon that is used for increasing microbial biomass and hence growth. $\mathrm{CO}_{2}$ is a common inorganic carbon source used for growth by organisms like eukaryotic algae, cyanobacteria, iron oxidizing bacteria (IOB) and sulfur oxidizing bacteria (SOB). This type of growth is referred to as autotrophic growth. Autotrophic microbes play a potentially important role in concrete biodegradation (as discussed below). Because $\mathrm{CO}_{2}$ is only a carbon source and not an energy source, energy must be supplied from photons or reduced inorganics like $\mathrm{H}_{2} \mathrm{~S}$ and FeS. Since $\mathrm{CO}_{2}$ is ubiquitous in air, provided enough of an energy source, (light or reduced inorganics), autotrophic activity is expected to persist.

Carbon dioxide concentrations are higher in vadose zones than in air, indicating that autotrophic activity in the vadose zone will not be hampered by low $\mathrm{CO}_{2}$ availability. For instance, with no underlying organic carbon contamination in the aquifer $\mathrm{CO}_{2}$ ranged from $1.45 \%$ to $3 \%$ at depths of 2.4 to 5.8 meters below ground surface in the US southwest [42] as well as the vadose zone at SRS [43]. Because of different diffusion properties, oxygen diffuses approximately $30 \%$ faster in the vadose zone than carbon dioxide under similar concentration gradients [42]. This suggests that oxygen is less likely to be growth limiting compared to carbon dioxide during autotrophic growth in the vadose zone surrounding concrete DUs housing LLW.

\subsubsection{Organic carbon}

In the environment, the main sources of organic carbon are from detritus (such as leaf litter and other decaying biomass), as well as root exudates. Cellular biomass and waste products produced by autotrophs will also contribute to organic carbon content to some degree. Nutrient breakdown from detritus degradation and subsequent flow-down through the vadose zone to the saturated zones (aquifers) provides subsurface microorganisms with carbon and energy for growth. The breakdown of organic carbon originating as plant detritus is a step-wise process that contributes to decreased $\mathrm{O}_{2}$ concentrations in the vadose and upper aquifer zones as well as supplying carbon and energy sources into the vadose zone and aquifer during recharge events. This process contributes to the energy input into the system that is responsible for driving biogeochemical changes as a result of microbial activity. So, while the respiratory and fermentative microbes responsible for this breakdown may not contribute to inorganic transformations directly, their activity is vital to the process as a whole.

Conversion of complex organics to non-fermentable carbon sources (i.e., acetate) provides a carbon source targeted for anaerobic respiring bacteria and thus favors the transformation of inorganic TEAs like nitrate, nitrite, nitrous oxide, ferric iron and sulfate. Gradients of TEAs and their reduced counterparts, as well as carbon sources, $\mathrm{H}_{2}, \mathrm{pH}$ and Eh are often results of microbial activity. Depletion of TEAs often follows a thermodynamic cascade with dissolved $\mathrm{O}_{2}$ the most energetically favorable. The bioavailability of a TEA may also contribute to its role in the rate of microbial activity. For example, solid phase TEAs (i.e., Fe(III) oxides) may be reduced simultaneously albeit at a slower rate, with soluble but less thermodynamically favorable $\mathrm{SO}_{4}$. Evidence of this phenomenon could be the presence of soluble $\mathrm{Fe}(\mathrm{II})$ and $\mathrm{H}_{2} \mathrm{~S}$, or soluble FeS. Gradation of metal contaminants (and hence microbial activity) may also occur as a result of preferential sorption to specific mineral types. 
SRNL-STI-2012-00435

Revision 0

\subsection{Physical structure of microbial communities}

\subsection{Biofilms}

In the environment, microorganisms are most often associated with biofilms on surfaces, including concrete structures, that can support robust biofilms [44]. Biofilms are defined as "matrix-enclosed bacterial populations adherent to each other and/or surfaces or interfaces" [45]. In these structures conditions can vary drastically relative to the external environment several millimeters away. Consequently these structures can support anaerobic biochemical reactions like methane production or acid production even though the bulk environment is aerobic or a neutral $\mathrm{pH}$ [46-48]. This suggests that the bulk conditions in the subsurface like DO or $\mathrm{pH}$ are not good predictors of microbial dynamics. In fact, biofilms on concrete have been shown to harbor complex microbial communities consisting of numerous bacterial and fungal species and with diverse and synergistic physiologies [44] [49] where each physiological trait comprises a "micro niche" inside the biofilm. The heterogeneity of physical and chemical parameters, even at the $\mathrm{mm}$ scale in biofilms is reflected in the heterogeneity of microbial populations in the bulk environment. Biofilms often sorb organic nutrients from the external environment as well as accelerate the leaching of inorganics like calcium from concrete[49], so in the case of oligotrophic systems, biofilms are more likely to form on surfaces because of higher nutrient availability[45].

The behavior of biofilms is predictable and therefore lends itself to mathematical modeling. Initial microbial interactions with surfaces like concrete, leading ultimately to surface associated biofilms can be explained by the Derjaguin-Landau-Verwey-Overbeek (DLVO) theory[50]. DLVO theory can be used to predict the interactions between attractive and repulsive forces associated with bacteria and surfaces that could lead to bacterial attachment. But this theory defines microorganisms as geometrically uniform and neglects to incorporate the role of bacterial surface components, including flagella, in the role of attachment[51]. Consequently the extended DLVO (XDLVO) has been developed to account for these differences[50].

\subsection{Physiology of relevant types of microorganisms}

A wide variety of microorganisms are capable of contributing to the degradation of concrete surfaces. A simplified illustration of complexity and inter-dependence of microorganisms in the environment, including concrete surfaces, is depicted in Figure 3. Table 1 provides an overview of the types of microbial physiology that are involved in reactions on concrete surfaces. These reactions range from those occurring on concrete exposed to air and sunlight as well as those in environments expected after the DUs are buried. Table 2 specifies some of the common acids produced during microbial growth and their corrosive properties. This section will provide some detail about the specific types of microorganisms and associated chemistries. 
Table 1. Types of microorganisms and physiologies involved in reactions on concrete

\begin{tabular}{|c|c|c|c|c|}
\hline Microbial type & C source & Energy & TEA & End products \\
\hline Algae \& Cyanobacteria & $\mathrm{CO}_{2}$ & Light & $\mathrm{O}_{2}$ & Organic acids, $\mathrm{O}_{2}, \mathrm{CO}_{2}$ \\
\hline Sulfur oxidizing bact. & $\mathrm{CO}_{2}$ & sulfides & $\mathrm{O}_{2}$ & Organic acids, $\mathrm{CO}_{2}, \mathrm{H}_{2} \mathrm{SO}_{4}$ \\
\hline Iron oxidizing bacteria & $\mathrm{CO}_{2}$ & $\mathrm{Fe}(\mathrm{II})$ & $\mathrm{O}_{2}$ & Organic acids, $\mathrm{CO}_{2}, \mathrm{Fe}(\mathrm{III}) \mathrm{OH}$ \\
\hline Nitrifying bacteria & $\mathrm{CO}_{2}$ & $\mathrm{NH}_{4}, \mathrm{NO}_{2}$ & $\mathrm{O}_{2}$ & Organic acids, $\mathrm{CO}_{2}, \mathrm{HNO}_{3}$ \\
\hline \multicolumn{5}{|l|}{ Heterotrophs } \\
\hline Aerobic respiration & Org. C & Org. C & $\mathrm{O}_{2}$ & Organic acids, $\mathrm{CO}_{2}$, \\
\hline \multicolumn{5}{|l|}{ Anaerobic respiration } \\
\hline Sulfate reducers & Org. C & Org. C & $\mathrm{SO}_{4}$ & Organic acids, $\mathrm{CO}_{2}, \mathrm{H}_{2} \mathrm{~S}$ \\
\hline Iron reducers & Org. C & Org. C & $\mathrm{Fe}(\mathrm{III})$ & Organic acids, $\mathrm{CO}_{2}, \mathrm{Fe}(\mathrm{II})$ \\
\hline NOx reducers & Org. C & Org. C & $\begin{array}{l}\mathrm{NO}_{3} \\
\mathrm{NO}_{2} \\
\mathrm{~N}_{2} \mathrm{O} \\
\end{array}$ & $\begin{array}{l}\text { Organic acids, } \mathrm{CO}_{2}, \mathrm{NO}_{2}, \mathrm{~N}_{2} \mathrm{O}, \mathrm{N}_{2} \\
\text { Organic acids, } \mathrm{CO}_{2}, \mathrm{~N}_{2} \mathrm{O}, \mathrm{N}_{2} \\
\text { Organic acids, } \mathrm{CO}_{2}, \mathrm{~N}_{2}\end{array}$ \\
\hline Anaerobic fermentation & Org. C & Org. C & Org. C & Organic acids, $\mathrm{CO}_{2}$, \\
\hline
\end{tabular}

Table 2. Strengths of some microbial acids which react with concrete and the solubility's of the associated calcium salts of concrete matrices[52].

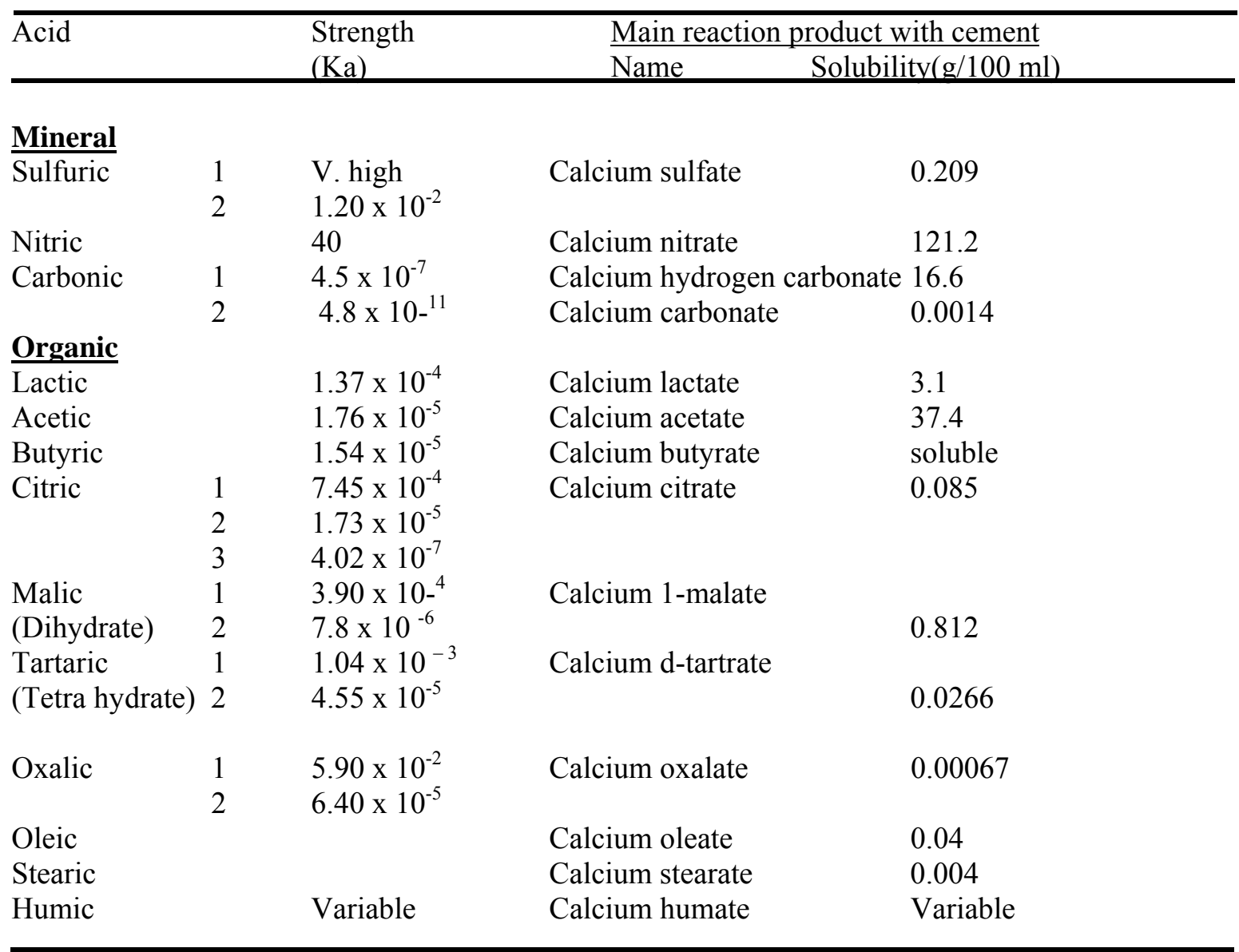

Strength in terms of $\mathrm{K}=[\mathrm{H} 1[\mathrm{~A}-] /[\mathrm{HA}]$ for the equilibrium $\mathrm{HA}=+\mathrm{A}$ in aqueous solution at $25^{\circ} \mathrm{C}$. Solubility in terms of $\mathrm{g} / 100 \mathrm{ml}$ cold water. Anhydrous salt unless otherwise stated. 


\subsection{Autotrophs}

Autotrophic microorganisms can utilize $\mathrm{CO}_{2}$ as a carbon source for growth. Energy for growth of these organisms is from a variety of sources such as light, or reduced chemicals like $\mathrm{H}_{2} \mathrm{~S}, \mathrm{Fe}$ (II), etc. The type of energy source used has been used to define these organisms taxonomically.

\subsubsection{Photoautotrophs}

In aerobic environments, concrete that is exposed to the air can become colonized by photosynthetic microorganisms like algae and cyanobacteria [53]. These photoautotrophs use energy from light and produce organic carbon from $\mathrm{CO}_{2}$ which is used for growth. Biofilms made up predominantly of algae and cyanobacteria are resistant to high levels of UV exposure and desiccation and are able to survive under these relatively harsh conditions. Damage to concrete can occur as a result of adsorption of chemicals necessary for microbial growth, like calcium and magnesium, from the concrete[54]. This process can lead to drying and cracking of the concrete.

As the biofilms mature, the population density and diversity of species present increases. In the increasing complexity of the microbial community in the biofilms, a variety of other physiological types can be encountered, as described below. In the case of SRS, SDF concrete DUs that are above ground are likely coated with a biofilm comprised of photoautotrophic biofilms. Ultimately when the SDF concrete DUs are buried, the existing biofilm will become less viable and serve as carbon sources for other types of microorganisms, as described below. This organic layer on the freshly buried concrete will likely serve as an organic carbon and energy source and accelerate initial growth of different, non-photoautotrophic microorganisms, now in the newly constructed vadose zone environment around the concrete DUs.

\subsubsection{Sulfur-oxidizing bacteria}

Sulfur oxidizing bacteria (SOB) play a key role in the overall biogeochemical cycling of sulfur. The sulfur cycle is complex, but the portions most pertinent to concrete degradation include sulfur oxidation and sulfate reduction. SOB are well documented in degradation of cement structures associated with nuclear waste containment $[55,56]$. In general, these bacteria grow at neutral to acidic $\mathrm{pH}$; can utilize $\mathrm{CO}_{2}$ and some organic carbon as a carbon source, reduced sulfur compounds such as metal sulfides and $\mathrm{H}_{2} \mathrm{~S}$ as energy sources and oxygen as the TEA.

Exceptions do exist however, for instance an alkaliphilic concrete degrading SOB was isolated and was shown to also be capable of using $\mathrm{NO}_{3}$ as a TEA [57]. During the course of growth reduced $\mathrm{S}$ is oxidized ultimately to $\mathrm{H}_{2} \mathrm{SO}_{4}$. In the environment the source of $\mathrm{H}_{2} \mathrm{~S}$ is likely the ubiquitous sulfate reducing bacteria (SRB) that function in anaerobic zones and are associated with the cycling of numerous $\mathrm{S}$ compounds (Table 3 ).

Table 3. Sulfur compounds associated with sulfate reduction

\section{Compound}

Organic S (R-SH)

Sulfide $\left(\mathrm{H}_{2} \mathrm{~S}\right)$

Elemental sulfur $\left(\mathrm{S}^{0}\right)$

Thiosulfate $\left(\mathrm{S}_{2} \mathrm{O}_{3}{ }^{2-}\right)$

Sulfur dioxide $\left(\mathrm{SO}_{2}\right)$

Sulfite $\left(\mathrm{SO}_{3}{ }^{2-}\right)$

Sulfate $\left(\mathrm{SO}_{4}{ }^{2-}\right)$

\section{Oxidation state}

$-2$

$-2$

0

+2 (average per $\mathrm{S}$ )

$+4$

$+4$

$+6$ 
Conversely, sulfate reducing bacteria (SRB) are strict anaerobes that can use a variety of carbon sources (Table 4) and typically do not tolerate $\mathrm{pH}$ values below 5.5. In this case, $\mathrm{SO}_{4}$ serves as the terminal electron acceptor with the resultant $\mathrm{HS}^{-}$released into the environment. The reactive HS $^{-}$can react with metals in solution and form sulfide minerals or it can be used by SOB as an energy source.

\section{Table 4. Common electron donors used in sulfate reduction}

$\mathrm{H}_{2}$
Lactate
Pyruvate
Ethanol and other alcohols
Fumarate
Malate
Choline
Acetate
Propionate
Butyrate
Long-chain fatty acids

Sulfate sources are ubiquitous in the environment as well as SRB and SOB. The population density of SOB, but not SRB, correlate reasonably well with corrosion rates of metals and concrete. As a result, the population density of SOB could serve as a rough estimate to predicting concrete biodegradation rates [58]. This is likely due to the ability of some SRB to form spores when not metabolically active and can skew population estimates of actively metabolizing bacteria during laboratory screening assays.

The process of SOB growth on concrete has been defined in three steps [59]. In step 1, prior to concrete degradation by $\mathrm{SOB}$, the $\mathrm{pH}$ of the concrete surface is reduced by atmospheric $\mathrm{CO}_{2}$ to around 9, which can facilitate growth of neutrophilic SOB. Based on XRD and SEM observations the surface at the end of step 1 is covered with calcium carbonate, resembling limestone more than concrete [60]. This process was reported to take around 56 days with step 2 progressing from day 56-day onward [59]. Growth continues in step 2 until a pH of about 4 is reached. At step 3, the population shifts to acidophilic SOB, which continue to drop in $\mathrm{pH}$ to around 1.0 [61] [55].

Growth rates $\left(\mathrm{d}^{-1}\right)$ of the common acidophilic SOB Acidithiobacillus thiooxidans were reported to range from $0.342-2.874$ between $\mathrm{pH} 0.9-4.3$, with optimum growth demonstrated in the $\mathrm{pH}$ range of $1.0-3.5$ [62]. In these studies, oxygen, $\mathrm{CO}_{2}$ and sulfide were not limited, so the growth rates are likely close to maximum growth rates. Oxygen consumption followed $\mathrm{H}_{2} \mathrm{~S}$ consumption very closely. Under environmental conditions, these parameters will likely be limiting to some degree and hence would control growth rates accordingly. For instance, vertical distributions of $\mathrm{SOB}$ were detected in direct correspondence to oxygen and $\mathrm{H}_{2} \mathrm{~S}$ concentrations with lower activity in more oxygen deplete zones [59]. This suggests that concrete structures in humid vadose zones are particularly prone to continuous microbial assault.

The lower $\mathrm{pH}$ results in dissolution of cement through leaching of ions. In addition the alkaline components of concrete like calcium react with $\mathrm{H}_{2} \mathrm{SO}_{4}$ to form gypsum $\left(\mathrm{CaSO}_{4}{ }^{\bullet} 2 \mathrm{H}_{2} \mathrm{O}\right)$. Due to the weak structural properties of gypsum, this process can lead to additional weakening of concrete[62]. The deposition of jarosite $\left(\mathrm{KFe}_{3}\left(\mathrm{SO}_{4}\right) 2(\mathrm{OH})_{6}\right.$ and gypsum are stimulated by $\mathrm{SOB}$ activity during concrete biodegradation [63]. During $\mathrm{SOB}$ growth, $\mathrm{H}_{2} \mathrm{SO}_{4}$ production reacts with 
$\mathrm{CaCO}_{3}$ to produce gypsum when $\mathrm{pH}$ levels are less than 3 [64]. The gypsum formation process continues into the concrete and increases the rate and degree of degradation due to the large density difference between the reaction products and concrete [55]. When newly formed gypsum reacts with less acidic $(\mathrm{pH}>3)$ calcium aluminate inside the concrete [64], this leads to formation of ettringite $\left(3 \mathrm{CaO}^{\bullet} \mathrm{Al}_{2} \mathrm{O}_{3} \cdot 3 \mathrm{CaSO}_{4} \cdot 32 \mathrm{H}_{2} \mathrm{O}\right)$. Ettringite is much more destructive because it increases the internal pressure leading to crack formation, which leads to increased surface area that is open to microbial activity and acid penetration. Previous work at SRS also demonstrated ettringite formation but not gypsum formation as a result of alkaline $\mathrm{SO}_{4}$ attack [65] with potential to weaken the concrete structural matrix. Presumably the higher $\mathrm{pH}$ values prevented gypsum formation in the previous study.

Concrete degradation rates have been recorded as the weight loss of concrete over time. These results can be accelerated which provides a rapid way to demonstrate the degree of degradation potential to the cement structure over longer time periods. Degrees of concrete degradation in accelerated studies ranged from $1.8 \%$ to $5.8 \%$ in 9 months $[66,67]$ with acidophilic SOB cultures and biogenic acid, respectively. Interestingly, studies incorporating neutrophilic SOB cultures demonstrated concrete degradation rates of as high as $16 \%$ within 4 weeks. This may have been due to a combination of the bacterial cultures used as well as the semi continuous growth conditions of the study [55]. After one year of incubation, Okabe et al. reported $40 \%$ weight loss of concrete, indicative of a 3-4 mm/year corrosion rate [59].

Various concrete formulations undergo acidic degradation to various rates and degrees [10, 68]. For instance, the use of silica fume as an additive to cement paste increase weight loss due to sulfur oxidation [69]. Biodegradation of concrete composed of various mortar mixes yielded very different results after one full year of exposure to SOB, incubated under optimum conditions [70, 71]. Based on weight losses due to biodegradation, less than $20 \%$ loss occurred with pure calcium aluminates. Calcium aluminates with silicious aggregate demonstrated $40 \%$ weight loss while Portland, blast furnace, calcium-sulfo-aluminate, and calcium aluminate/slag cements were almost completely destroyed after one year of incubation. This assay was designed to accelerate concrete biodegradation by 16 times.

Components of cement have also been shown to inhibit SOB activity. Calcium formate proved to completely inhibit SOB isolated from a various locations [10]. In this study, different concentrations of calcium formate were incorporated into concrete through a weight ratio of 2:6:1 (cement:sand:water). Calcium formate was added at various concentrations in substitution for water. $10 \mathrm{mM}$ of calcium formate demonstrated inhibitory effects on some SOB isolates while $50 \mathrm{mM}$ or greater of calcium formate had a profound inhibitory effect on all isolates studied for up to 38 days. Long-term tests under environmental conditions are needed to further understand the potential of this approach.

Surface contact onto concrete by bacterial biofilms (discussed in some detail below) increases the concentration of degrading metabolites to a greater degree than just soluble chemicals alone, resulting in an increase of concrete degradation deeper into the matrix [9]. This is the reason that chemical tests alone do not adequately estimate microbial damage to concrete [68]. As microbial corrosion proceeds, increases in the porosity and surface roughness become evident on concrete surfaces [72]. As a result of the increased roughness of the concrete surface, the increase in exposed surface area will also contribute to increased rates of microbial contact and biodegradation. 


\subsubsection{Iron oxidizing bacteria}

Iron exists naturally as ferrous $\left(\mathrm{Fe}^{2+}\right)$ and ferric $\left(\mathrm{Fe}^{3+}\right)$ oxidation states. Ferric iron reduction is common in soils with the ferric iron often serving as an electron acceptor for anaerobic respiration. This reaction can occur when ferric iron is in solution or if it is in solid form as a ferric oxide. The presence of humic compounds can accelerate this process because they act as electron shuttles [40,41]. The resulting ferrous iron can be assimilated biologically, react with other metals in solution or oxidize rapidly if it diffuses into aerobic zones. Ferrous iron can also be oxidized by iron oxidizing bacteria either in non-acidic, nutrient rich aerobic zones where ferrous iron is chelated to humics, or in acidic zones where ferrous iron is stable.

Iron oxidizing bacteria (IOB) are similar to SOB except they utilize ferrous iron as an energy source and may accelerate the corrosion of steel rebar used as reinforcement in concrete structures. Exposure of the rebar in the concrete to the environment can occur through microbial corrosion or abiotic corrosion. In any event the exposed steel is a likely energy source for IOB. In the presence of biofilms with $\mathrm{SOB}$ activity, the resulting low $\mathrm{pH}$ will increase $\mathrm{Fe}^{2+}$ solubility and IOB activity. IOB enhanced pitting corrosion as determined through electrochemical impedance spectroscopy and scanning electron microscopy in the presence of steel coupons, compared to sterile controls. Follow on studies demonstrated that compared to iron oxidizers alone, steel exposure to iron oxidizers and SRB together resulted in a synergistic effect on the steel, demonstrating a greater degree of corrosion than IOB or SRBs alone [73]. In addition, along with $\mathrm{SOB}$, as described above, IOB were inhibited by various concentrations of calcium formate when added to cement [10].

\subsubsection{Nitrifying bacteria}

Nitrifying bacteria are similar to sulfur oxidizers in as much as they can use $\mathrm{CO}_{2}$ or carbonate as a carbon source. They differ from sulfur oxidizers based on their energy source for growth. Nitrifying bacteria obtain energy through the oxidation of $\mathrm{NH}_{4}{ }^{+}$or $\mathrm{NO}_{2}^{-}$, ultimately to $\mathrm{NO}_{3}{ }^{-}$, resulting in nitric acid production. Nitrifying bacteria have been detected in a wide variety of environments and are more tolerant to low water activity than sulfur oxidizers[49].

Microbial activity is responsible for catalyzing a majority of redox reactions involving nitrogen (Fig. 4.). Similarly, nitrogen is a major requirement for microbial growth as a component of proteins and other cellular constituents but also as alternative terminal electron acceptors in a number of anaerobic respiratory reactions. In general, $\mathrm{N}_{2}$ is incorporated into soils by nitrogen fixing bacteria and converted to $\mathrm{NH}_{3}$ for assimilation into cellular biomass. $\mathrm{NH}_{2}$ is also assimilated and is a reduction product from $\mathrm{NO}_{3}$ as a result of biomass decomposition. $\mathrm{NO}_{3}$ can also undergo dissimilatory reduction by use as a TEA, in lieu of oxygen. In this case $\mathrm{NO}_{3}$ is reduced step-wise to $\mathrm{NO}_{2}, \mathrm{~N}_{2} \mathrm{O}$ and then to $\mathrm{N}_{2}$.

Biogenic nitric acid production from ammonia and nitrite oxidizing bacteria demonstrated significantly greater concrete destruction when concrete consisted of blast furnace slag and Portland cement[74]. Biodegradation was due to calcium dissolution and was greater when compared to abiotic chemical attack from ammonium chloride[75]. 


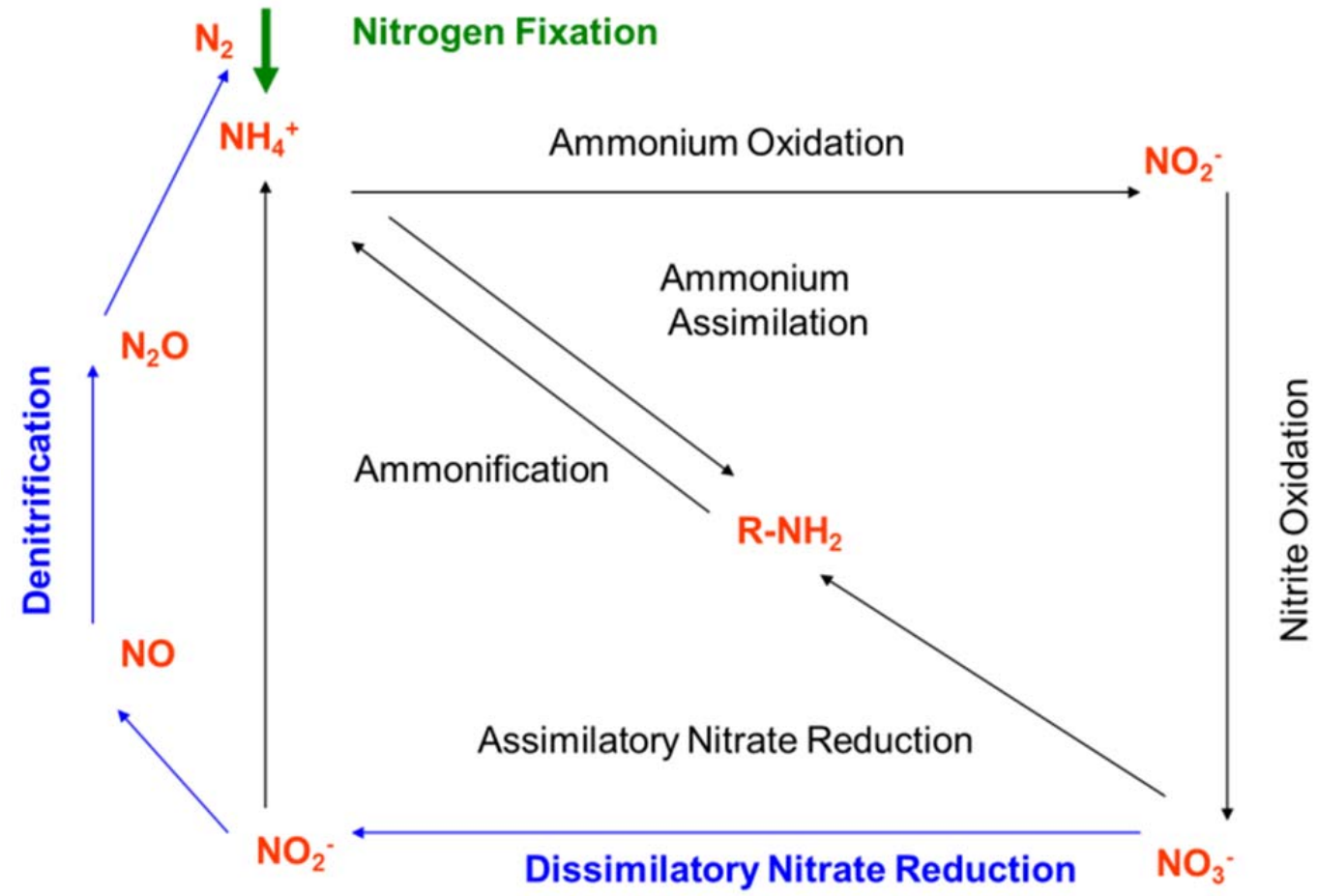

Figure 4. Depiction of the role of microorganisms in nitrogen cycling

\subsection{Heterotrophic microorganisms}

Heterotrophic microorganisms require organic carbon as a source of carbon and energy for growth.

\subsubsection{Aerobic heterotrophs}

In aerobic environments like the vadose zone, and especially on concrete exposed to the air, growth with oxygen as TEA could predominate. In this scenario, fungi may play a significant role in this process due to their rapid growth rates and greater tolerance of low water availability and $\mathrm{pH}$ ranges [60]. In addition rock-inhabiting fungi demonstrate enough mechanical strength in their hyphae to penetrate into crevices for nutrients. Fungi in this case, especially those that produce melanin, which confers extra-mechanical strength, can rapidly penetrate millimeters to centimeters into concrete-like structures $[9,53,60]$. Fungi also can produce peroxide, by the enzyme peroxidase. This is usually associated with their ability to breakdown complex organic molecules to serve as carbon and energy sources. These reactions in close association to concrete will likely have deleterious effects on the concrete structure[49]. These organisms can serve as primary colonizers that potentially condition the surface for other microorganisms, like fermenters or sulfur oxidizers. 


\subsubsection{Anaerobic heterotrophic fermentation}

Heterotrophic microorganisms comprise a large segment of environmental inhabitants capable of growth on concrete. In particular this type of microorganism uses organic carbon as a carbon and energy source. For the most part, acid production occurs during anaerobic growth when fermentation is the primary type of growth[56]. Fermentation conditions can occur as a result of increased microbial biomass and activity which can decrease dissolved oxygen levels. Fermentation rates will be linked to the availability of organic carbon and in turn, acid by products will be controlled by the type of organic carbon used for growth as well as the type(s) of microbes present. Since fermentation is an incomplete oxidation of organic carbon, many organic acids are produced as by products (Fig. 3; Tables 1 and 2). Because of the physiological diversity of this group of microorganisms, their numbers and growth potential make them common in practically all environments, hence they will take part in concrete biodegradation processes. Their diverse physiologies provides for a wide range of acid by-products such as, lactic, citric, gluconic, malic and many others. A description of concrete biodegradation by a pure culture identified intense chemical zonation and decalcification in the concrete matrix due to the close proximity of fermenters to the concrete surface[9].

\subsubsection{Anaerobic heterotrophic respiration}

Bacteria that can undergo respiration without the need for oxygen must utilize other TEAs. In relation to concrete degradation sulfate reducing bacteria contribute significantly to this process both directly and indirectly. Indirectly, (as mentioned above), sulfate reduction is responsible for $\mathrm{H}_{2} \mathrm{~S}$ production, which can feed into sulfur oxidizing metabolism resulting in $\mathrm{H}_{2} \mathrm{SO}_{4}$ production and concrete degradation. In addition, $\mathrm{H}_{2} \mathrm{~S}$ can contribute directly to concrete structure degradation through penetration into concrete and contribute to both concrete and metal rebar corrosion [49]. Because concrete structures are reinforced with steel rebar, structural degradation of these reinforcements over many years may contribute to significant corrosion and structural instability.

\subsection{Potential interactions of biofilms on SDF DU concrete.}

\subsection{Probable progression of events relative to biofilm formation}

Based on the literature available to date it is possible to construct a chronological scenario relative to biofilm activity on the concrete DUs housing saltstone grout at SRS. Since the conditions of the saltstone grout itself are too high in $\mathrm{pH}$ and osmotic pressure to support microbial growth, growth is only expected to occur in association with the concrete surface exposed to the environment.

Based on the literature reviewed above, biofilm formation on the concrete surface of SDF DUs housing saltstone will follow several stages as the concrete DUs transition from above ground to buried. While above ground photoautotrohic biofilms likely exist and support complex assemblages of heterotrophic bacteria and fungi. This biofilm could increase surface drying and cracking of the concrete, resulting in increased surface area exposed to the environment.

After burial, the shift in environmental conditions will cause a die-off of the photosynthetic microbes and result in a sudden availability of organic carbon that could accelerate new biofilm growth. The nature of the biofilm will likely ultimately be acidic and possibly as low as a $\mathrm{pH} \sim 1$. If the concrete is degraded substantially over time, the acidic biofilm will diminish the structural 
integrity of the concrete and could cause premature leakage of saltstone contaminate into the environment. The time scale of structural degradation will be based on the rate of microbial activity. The microbial activity will be directly tied into physiochemical conditions in the subsurface and bioavailability of carbon and energy sources as well as TEAs. Attempts at predicting microbial activity and biofilm production, related to concrete biodegradation could focus on the geochemistry of the immediate environment and energetics and physiology of the system as it relates to SOB, IOB and nitrifying bacteria.

A second consideration is the fate of leaching saltstone when its first contact out of the containment vault will be low $\mathrm{pH}$ biofilms on microbial weathered concrete. How will the extremely alkaline $(\mathrm{pH}>12)$ saltstone react with concrete if the concrete has been structurally compromised and may contain significant amounts of gypsum, jarosite and / or ettringite?

In addition, the effect of the acidic biofilm chemistry on alkaline saltstone as it trickles out of the vault may also need to be considered. The saltstone leachate is expected to kill microbes in the biofilm. However, the acidic, organic structure remaining may change the chemistry of the saltstone leachate enough to alter its behavior in the environment. Will the very acidic $(\mathrm{pH} \sim 1-3)$ biofilm provide some degree of buffering to the saltstone when the two contact each other? The rate at which the saltstone leachate contacts the biofilm of the exterior surface of the concrete containment will play a major role as to the potential effects of biofilm chemistry on the saltstone.

Sulfate and nitrate diffusion into the subsurface from saltstone leachate may also contribute to additional concrete biodegradation. This would be as a result of sulfate reduction to sulfides and nitrate reduction to $\mathrm{NH}_{4}$ and $\mathrm{NO}_{2}$. These resulting chemicals could be oxidized by microorganisms to acids, further degrading the concrete vault structures.

\subsection{Considerations for predicting and minimizing biofilm formation of concrete and environmental monitoring}

\subsection{Modeling parameters}

An understanding of the geochemistry and microbiology of the soils surrounding the concrete DUs will be required for predicting the rate of flux of electron donors like sulfides and nitrogen compounds that could be used by SOBs and nitrifying bacteria. The organic carbon content of underlying soils will also be useful in predicting rates of microbial activity. These parameters together could be used to predict the rate of concrete biodegradation.

\subsection{Considerations for minimizing biofilm formation on buried concrete DUs}

Based on the literature to date, specific environmental conditions in close proximity of the concrete DUs could be controlled to drastically minimize microbial activity and resulting concrete biodegradation after vault burial. Several steps could include:

1. Maintain dry conditions around the buried DUs,

2. Minimize organic carbon flux in the soil such as plant root exudates,

3. Remove existing biofilms from concrete prior to vault burial,

4. Consider coating the concrete surface to minimize microbial activity,

5. Choose fill soil that does not support microbial growth very well (i.e low in organics and little microbial activity) and especially low in sulfates and nitrates. 


\subsection{Insights for future environmental monitoring approaches}

Along with thorough modeling to predict contaminant fate, other approaches are often included that add a level of conservatism to the effort. These include monitoring wells installed down gradient from the burial site that provide a level of assurance that no contaminants have leaked out or that the containment efforts have been breached $[14,15]$. Emerging technologies that incorporate an understanding of microbial activity and subsequent biogeochemical changes, especially mineral transformations, are included in emerging biogeophysical approaches. These techniques provide microbial and geochemical data by incorporating electrochemical impedance analysis [76] and offer potential in providing a monitoring or sentinel approach that can target specific redox reactions and resultant mineral formations. Another advantage is that these techniques can be conducted remotely using existing electrodes and can also screen more subsurface area and are more cost effective when used in conjunction with monitoring wells.

\subsection{Conclusions}

The saltstone wastes, when stored in concrete DUs are not expected to be impacted by microbial activity due to the high $\mathrm{pH}$ and osmotic pressures of these low level radioactive wastes. The concrete DUs in which the saltstone waste is disposed will be impacted by microbial growth and will in turn be impacted by some degree of biodegradation. The microbial activity will occur on the outside of the concretes DUs exposed to the vadose zone environment.

The rate and degree of concrete biodegradation will depend on geochemical and physical parameters that control microbial activity as well as the presence of specific physiological types of microorganisms. Specific parameters include availability and abundance of energy sources like components involved in sulfur, iron and nitrogen oxidation, as well as TEAs, especially $\mathrm{SO}_{4}$, $\mathrm{Fe}(\mathrm{III}), \mathrm{NO}_{3}, \mathrm{NO}_{2}$ and $\mathrm{O}_{2}$. Carbon flow and bioavailability to microorganisms are also factors to consider in modeling concrete biodegradation. The rate and degree of microbial activity at any given place is dependent on a variety of parameters that contribute to microbial growth and activity.

Incorporation of pertinent parameters into a model is possible for predictive purposes, especially if microbial activity is viewed as a complex series of catalytic reactions. The ability for microbes to adapt to specific conditions as well as environmental selection for specific microbial types should also be considered in the models. Preventative approaches that minimize microbial activity will likely contribute significantly to decreasing the rate of concrete biodegradation.

\subsection{Acknowledgements}

We would like to thank C. Langton, R. Brigmon, M. Kingsley, G. Flach, M. Reigel, M, Millings, D. Kaplan, M. Phifer, M. Heitkamp, M. Serrato, H. Burns and K. Rosenberger for helpful insights and technical discussions. We would also like to thank D. Holiday and L. Nelson for technical support in document preparation. 


\subsection{References}

1. Rogers, R.D., M.A. Hamilton, and J.W. McConnell, Microbial-Influenced Cement Degradation - Literature Review, 1993, EG\&G Idaho, Inc.: Idaho National Engineering Laboratory.

2. NRC, Licensing Requirements for Land Disposal of Radioactive Wastes, in 10 CFR 611982, Office of the Federal Register.

3. Rogers, R.D., M.A. Hamilton, and J.W. McConnell, The possibility for microbially influenced degradation of cement solidified low-level radioactive waste forms. Mater. Res. Soc. Symp. Proc., 1993. 294(Scientific Basis for Nuclear Waste Management XVI): p. 261-6.

4. Rogers, R.D., M.A. Hamilton, and J.W. McConnell, Jr., Microbially influenced degradation of cement solidified low-level radioactive waste forms. Geol. Confinement Dechets Toxiques GEOCONFINE 93, Actes Symp. Int., 1st, 1993. 1: p. 257-63.

5. Hamilton, M.A., et al., Evaluation of microbially influenced degradation of massive concrete structures. Mater. Res. Soc. Symp. Proc., 1996. 412(Scientific Basis for Nuclear Waste Management XIX): p. 469-74.

6. Rogers, R.D., Effects of microbially influenced degradation on massive geothermal field concrete structures. Corros. Rev., 1999. 17(3-4): p. 155-166.

7. Rogers, R.D., M.A. Hamilton, and L.O. Nelson, Microbially influenced degradation of concrete structures. Proc. SPIE-Int. Soc. Opt. Eng., 1998. 3398(Nondestructive Evaluation of Utilities and Piplines II): p. 194-199.

8. ROGERS, R.D., et al. Development of the Methodology to Evaluate Microbially Influenced Degradation of Cement-solidified Low-level Radioactive Waste Forms. in Symposium V-Scientific Basis for Nuclear Waste Management XVII 2003. Published online by Cambridge University Press: 2011.

9. Magniont, C., et al., A new test method to assess the bacterial deterioration of cementitious materials. Cem. Concr. Res., 2011. 41(4): p. 429-438.

10. Yamanaka, T., et al., Corrosion by bacteria of concrete in sewerage systems and inhibitory effects of formates on their growth. Water Res., 2002. 36(10): p. 2636-2642.

11. Thullner, M., P. Regnier, and P. Van Cappellen, Modeling Microbially Induced Carbon Degradation in Redox-Stratified Subsurface Environments: Concepts and Open Questions. Geomicrobiol. J., 2007. 24(3-4): p. 139-155.

12. Meike, A. and S. Stroes-Gascoyne, Review of Microbial Responses to Abiotic Environmental Factors in the Context of the Proposed Yucca Mountain Repository, 2000, Lawrence Livermore National Laboratory.

13. Silva, M.R., Climates and biodeterioration of concrete. Durability Build. Mater. Compon. 7, Proc. Int. Conf., 7th, 1996. 1: p. 191-200.

14. Al Tabbaa, A. and A. Perera, UK stabilization/solidification treatment and remediation Part I: binders, technologies, testing and research. Land Contamination and Reclamation. Land Contamination and Reclamation, 2006. 14: p. 1-22.

15. Al Tabbaa, A. and A. Perera, UK stabilization/solidification treatment and remediation Part II: performance, QA/QC and guidance documents. Land Contamination and Reclamation, 2006. 14: p. 23-41.

16. Serne, R.J. and J.H. Westsik, Data Package for Secondary Waste Form DownSelection-Cast Stone, 2011. p. Medium: ED; Size: PDFN.

17. Dixon, K., J. John Harbour, and M. Mark Phifer, Hydraulic and Physical Properties of Saltstone Grouts and Vault Concretes, 2008. p. Medium: ED.

18. Flach, G., J.M. Jordan, and T. Whiteside, Numerical Flow and Transport Simulations Supporting the Saltstone Facility Performance Assessment, 2009. p. Medium: ED. 
19. Cook, J., Special Analysis: Revision of Saltstone Vault 4 Disposal Limits (U), 2005. p. Medium: ED.

20. Dixon, K.L., Concrete Mixes for Saltstone Vault 4, 2005, Westinghouse Savannah River Company: Aiken, SC. p. 4.

21. Albenesius, E.L., Computer Modeling of Saltstone Landfills by Intera Environmental Consultants, in Other Information: PBD: 9 Aug 20012001. p. Medium: ED; Size: vp.

22. Hoeffner, S.L., Strontium Sorption onto SRP Soils, in Other Information: PBD: 2 Jul 20012001. p. Medium: ED; Size: vp.

23. McDowell-Boyer, L.M., Long Term Uncertainty in Radiological Performance Assessments of Low Level Waste Facilities at Savannah River Site, in Eighth World Congress of the International Radiation Protection Association 1992: Montreal, Quebec, Canada.

24. Hiergesell, R., Nitrate Diffusional Releases from the Saltstone Facility, Vault 2, with Respect to Different Concrete Wall Thicknesses, in Other Information: PBD: 31 Jan 20052005. p. Medium: ED; Size: vp.

25. Dixon, K. and M. Mark Phifer, Hydraulic and Physical Properties of MCU Saltstone, 2008. p. Medium: ED.

26. Nichols, R. and K. Dixon, Permeability of Testing of Simulated Saltstone Core and Vault 4 Cell E Saltstone, 2011. p. Medium: ED.

27. Phifer, M.A., M.R. Millings, and G.P. Flach, Hydraulic Property Data Package for the E-Area and Z-Area Soils, Cementitious Materials, and Waste Zones, 2006.

28. Williams, F. and J. Harbour, Impact of Curing Temperature on the Saturated Liquid Permeability of Saltstone, 2011. p. Medium: ED.

29. Almond, P.M. and D.I. Kaplan, Distribution Coefficients (Kd) Generated from a Core Sample Collected from the Saltstone Disposal Facility, 2010.

30. Kaplan, D., et al., Technetium Sorption by Cementitious Material Under Reducing Conditions, 2012. p. Medium: ED.

31. Kaplan, D., et al., Long-term Technetium Interactions with Reducing Cemntitious Materials, 2011. p. Medium: ED.

32. Roberts, K. and D. Kaplan, Reduction Capacity of Saltstone and Saltstone Components, 2009. p. Medium: ED.

33. Phifer, M.A., Saltstone Disposal Facility Closure Cap Configuration and Degradation Base Case: Institutional Control to Pine Forest Scenario, in Other Information: PBD: 19 Mar 20042004. p. Medium: ED; Size: vp.

34. Bannochie, C., Saltstone 4QCY11 TCLP Results, 2012. p. Medium: ED.

35. Cozzi, A. and A. Duncan, Characterization of Core Sample Collected from the Saltstone Disposal Facility, 2010. p. Medium: ED.

36. Reigel, M. and W. Cheng, Analysis of the Salt Feed Tank Core Sample, 2012. p. Medium: ED.

37. B., A. and M. F., Biochemical Engineering and Biotechnology Handbook. 1991, New York: Stockton Press.

38. Madigan , M.T., J. Martinko, and J. Parker, Microbial Growth, in Biology of Microorganisms. 2003, Pearson Education: London. p. 151-165.

39. Madigan , M.T., J. Martinko, and J. Parker, Metabolic Diversity, in Biology of Microorganisms. 2003, Pearson Education: London. p. 151-165.

40. Lovley, D.R., et al., Humic substances as electron acceptors for microbial respiration. Nature (London), 1996. 382 p. 445-448

41. Turick, C.E., L.S. Tisa, and F.J. Caccavo, Melanin production and use as a soluble electron shuttle for $\mathrm{Fe}(\mathrm{III})$ oxide reduction and as a terminal electron acceptor by Shewanella algae BrY. Appl. Environ. Microbiol. , 2002. 68: p. 2436-2444. 
42. Suchomel, K.H., D.K. Kreamer, and A. Long, Production and transport of carbon dioxide in a contaminated vadose zone: a stable and radioactive carbon isotope study. Environ. Sci. Technol., 1990. 24(12): p. 1824-1831.

43. Millings, M.R., Summary Carbon Dioxide in Water Table Wells and the Vadose Zone at SRS, 2012, Savannah River Nuclear Solutions: Aiken, SC.

44. Vincke, E., N. Boon, and W. Verstraete, Analysis of the microbial communities on corroded concrete sewer pipes - a case study. Appl. Microbiol. Biotechnol., 2001. 57(56): p. 776-785.

45. Costerton, J.W. and Z. Lewandowski, Microbial Biofilms. Annu. Rev. Microbial. J 1995. 49: p. 711-745.

46. Chen, G.-H., D.H.W. Leung, and J.-C. Hung, Biofilm in the sediment phase of a sanitary gravity sewer. Water Res., 2003. 37(11): p. 2784-2788.

47. Satoh, H., et al., Microbial community structures and in situ sulfate-reducing and sulfuroxidizing activities in biofilms developed on mortar specimens in a corroded sewer system. Water Res., 2009. 43(18): p. 4729-4739.

48. Herb, S., et al., Characterization of biofilms on corroded concrete surfaces in drinking water reservoirs. Water Sci. Technol., 1995. 32(8): p. 141-147.

49. Gu, J.D., T.E. Ford, and R. Mitchell, Microbiological corrosion of concrete. Uhlig's Corros. Handb. (3rd Ed.), 2011: p. 451-460.

50. Chia, T.W.R., et al., Stochasticity of Bacterial Attachment and Its Predictability by the Extended Derjaguin-Landau-Verwey-Overbeek Theory. Appl. Environ. Microbiol., 2011. 77(11): p. 3757-3764.

51. Caccavo, F. and A. Das, Adhesion of Dissimilatory Fe(III)-Reducing Bacteria to Fe(III) Minerals. Geomicrobiol. J., 2002. 19(2): p. 161-177.

52. Page, C.L. and M.M. Page, Durability of Concrete and Cement Composites. 2007, Boca Raton, FL: CRC Press LLC.

53. Gorbushina, A., Life on the rocks. Environmental Microbiology, 2007. 9(7): p. 16131631.

54. Javaherdashti, R., et al., On the Impact of Algae on Accelerating the Biodeterioration/Biocorrosion of Reinforced Concrete: A Mechanistic Review European Journal of Scientific Research, 2009. 36(3): p. 394-406.

55. Aviam, O., et al., Accelerated biodegradation of cement by sulfur-oxidizing bacteria as a bioassay for evaluating immobilization of low-level radioactive waste. Appl. Environ. Microbiol., 2004. 70(10): p. 6031-6036.

56. Spor, H., M. Trescinskia, and M.F. Liberta. Microbial Effects on the Radionuclide Transport in a Deep Nuclear Waste Repository. in MRS Proceedings 1992. 1992. Published online by Cambridge University Press: 2011.

57. Maeda, T., et al., Isolation of a sulfur-oxidizing bacterium, that can grow under alkaline pH, from corroded concrete. Biosci., Biotechnol., Biochem., 1998. 62(6): p. 1087-1092.

58. Javaherdashti, R., Impact of sulphate-reducing bacteria on the performance of engineering materials. Appl. Microbiol. Biotechnol., 2011. 91(6): p. 1507-1517.

59. Okabe, S., et al., Succession of sulfur-oxidizing bacteria in the microbial community on corroding concrete in sewer systems. Appl. Environ. Microbiol., 2007. 73(3): p. 971-980.

60. Wiktor, V., et al., Accelerated weathering of cementitious matrix for the development of an accelerated laboratory test of biodeterioration. Mater. Struct., 2011. 44(3): p. 623-640.

61. Knight, J., C. Cheeseman, and R. Rogers, Microbial influenced degradation of solidified waste binder. Waste Manage. (Oxford, U. K.), 2002. 22(2): p. 187-193.

62. Jensen, H.S., et al., Growth kinetics of hydrogen sulfide oxidizing bacteria in corroded concrete from sewers. J. Hazard. Mater., 2011. 189(3): p. 685-691.

63. Tazaki, K., T. Mori, and T. Nonaka, Microbial jarosite and gypsum from corrosion of portland cement concrete. Can. Mineral., 1992. 30(2): p. 431-4. 
64. Mori, T., et al., Interactions of nutrients, moisture and $\mathrm{pH}$ on microbial corrosion of concrete sewer pipes. Water Res., 1992. 26(1): p. 29-37.

65. <langton 2008.pdf>. 2008.

66. Sand, W., Microbial mechanisms of deterioration of inorganic substrates - A general mechanistic overview. Int. Biodeterior. Biodegrad., 1997. 40(2-4): p. 183-190.

67. Sand, W. and E. Bock, Biodeterioration of concrete by thiobacilli and nitrifying bacteria. Mater. Tech. (Paris), 1990. 78(No. Spec.): p. 70-2.

68. O'Connell, M., C. McNally, and M.G. Richardson, Biochemical attack on concrete in wastewater applications: A state of the art review. Cem. Concr. Compos., 2010. 32(7): p. 479-485.

69. Fisher, M., et al., The effect of silica fume on biodegradation of cement paste and its capacity to immobilize strontium during exposure to microbial sulfur oxidation. Biodegradation, 2008. 19(3): p. 321-328.

70. Zimmermann, C.M., U.A. Laskay, and G.P. Jackson, Analysis of suspected trace human remains from an indoor concrete surface. J. Forensic Sci., 2008. 53(6): p. 1437-1442.

71. Ehrich, S. and E. Bock, Biogenic sulfuric acid corrosion. Test procedure for cementbound materials. DECHEMA Monogr., 1996. 133(Biodeterioration and Biodegradation): p. 193-198.

72. Harbul'akova, V.O., et al., Changes of porosity and roughness of concrete surfaces due to microbial corrosion. J. Chem. Chem. Eng., 2011. 5(3): p. 241-245.

73. Xu, C., et al., Pitting corrosion behavior of 316L stainless steel in the media of sulfatereducing and iron-oxidizing bacteria. Mat Character, 2008. 59: p. 245-255.

74. Jozsa, P.G., et al., Statistical data analysis of microbially influenced deterioration of concrete. DECHEMA Monogr., 1996. 133(Biodeterioration and Biodegradation): p. 199208.

75. Jozsa, P.G., M. Kussmaul, and E. Bock, Simulation of concrete corrosion by nitrifying bacteria. DECHEMA Monogr., 1996. 133(Biodeterioration and Biodegradation): p. 127134.

76. Atekwana, E.A. and L.D. Slater, Biogeophysics: A new frontier in Earth science research. Rev. Geophys., 2009. 47(4): p. RG4004. 


\section{Distribution:}

\section{SRNS}

R. S. Aylward, 773-42A

H. H. Burns, 773-41A

A. D. Cozzi, 999-W

D. A. Crowley, 774-43A

G. P. Flach, 773-42A

K. M. Fox, 999-W

S. L. Marra, 773-A

C. Wilson (1 file copy \& 1 electronic copy), 773-43A - Rm.213

SRR

T. W. Coffield, 705-1C

K. A. Hauer, 705-1C

K. H. Rosenberger, 705-1C

F. M. Smith, 705-1C

K. H. Subramanian, 766-H

DOE

P. R. Jackson, 703-46A (1 file copy \& 1 electronic copy), 77343A - Rm.213 